\title{
Design management approach to create strategies and cross the line at the bottom of the pyramid markets
}

\author{
[Diego H. Florez Ayala - Álvaro G. R. Lezana]
}

\begin{abstract}
-this article discusses how the design management is an enabler that generates innovation and transformation, more effective and success for the organization and entrepreneurs who want to develop products, services and operations in the bottom of pyramid markets. This is a market with many difficulties, but with many opportunities. The objective of this article is identifying opportunities, strategies and methods to support organizations and for entrepreneurs to enter to the bottom of pyramid markets. Also, have the opportunity to design products, services and innovative and sustainable operations through design management in order to generate profits for them, and positive impacts for this population. The type of research is qualitative based on secondary sources studies, research and academic papers and case studies of organizations that work for this population. The steps described in this article aboard the issues, fundamental concepts of bottom of the pyramid and design management, organization cases and entrepreneurs, using design management, developing the process for boarding with success to this market.
\end{abstract}

Keywords-Design management, Strategy, Bottom of the pyramid, Strategic management of Design

\section{Introduction}

For making business with four billion poorest people in the world -two-thirds of the global population- are required radical innovations in technology and business models (PRAHALAD, C.K.; HART, s., 2002). To work with this market, entrepreneurs and organizations have to meet the challenges affecting this population, in order to improve people's quality of life and reduce the inequality index, being necessary for this, design appropriate products and services for this population.

According to Prahalad (2011), accessibility is necessary, but not enough, tastes and aspirations change rapidly, this is precisely what can make the Bottom of the pyramid (BoP) an important platform of knowledge and that with the support of the management of the design can meet. To do this, if you must obtain insights about usability, meet income volatility of this population for to generate profits.

Diego Hernando Florez Ayala

Federal University of Santa Catarina

Brazil

Alvaro G. R. Lezana

Federal University of Santa Catarina

Brazil
These hurdles are the suspicion or the low attractiveness of the population of the bottom of the pyramid ( $\mathrm{BoP}$ ) for effective profits generation. These limitations make the market unattractive for both organizations and entrepreneurs, which generally want to generate wealth in short time. Due to this, the main bias in business development it is economical, leaving out the social and the environmental.

The problems is identify how design management can help organizations and entrepreneurs to enter, develop and approach products and services in the markets at the bottom of the pyramid, and so generate opportunities with a positive impact to this population and for organizations and entrepreneurs

To enter these markets, there are some strategic challenges of design management in order to generate a transformation of impact (Prahalad, 2011). One of the lessons of design that must be taken into consideration are the usability and adaptability of the product packaging, i.e. its presentation; a good example is the jelly container in Colombia, which had an increase in the number of sales, after the discovery by the companies of multi-functionality, which after consumption of the product, turn a glass. For families, it is a good deal, food and glass, two for one (MARKETING NEWS, 2014). Another way to enter the bottom of the pyramid markets is to include the client as part of the production chain, and the sales of its products and services. In addition to these strategies, there is the possibility to make strategic partnerships with different sectors to the core business of the organization.

The purpose of this article is to identify strategies and methods that enable organizations and entrepreneurs join the Bottom of the pyramid markets. Also, have the opportunity to design products, services and innovative, sustainable operations through design management in order to generate profits to organizations and entrepreneurs, and a positive impact for this population.

\section{Method}

In this step of the research project presented the methods and techniques to use in the research:

\section{A. Based on approach of the research}

The typology of research is qualitative, according to Minayo (1998), the qualitative studies respond to particular issues, worrying about a level of reality that not be quantified. That is, enter the universe of the behaviors, attitudes and values underlying the object and the context researched, seeking the meaning of variables that not be reduced to quantification. 


\section{B. Based on objectives}

According to Gil (1995), the traditional way, the research based on their objectives as descriptive, explanatory and exploratory evaluation. This research characterized as exploratory, having as main purpose to develop, clarify and modify concepts and ideas, with views on the formulation of problems.

\section{Based on technical procedures}

The procedure and grounds for realization of this article is based on secondary source studies and research in academic articles and scientific bases. The literature search conducted through consultation in scientific database, according to a methodological strategy that shows the figure 1 .

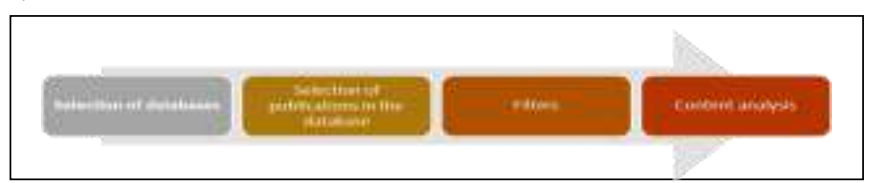

Figure 1. Methodological Strategy (Developed by the author)

\section{a) Selection of database}

The database consulted for meet the search criteria were in Scopus (with a database of abstracts, citations from scientific literature and sources of information on the Internet, with more than 15,000 magazines), and Science Direct (scientific database, journal articles and chapters of books of more than 2,500 journals and nearly 20,000 books). Similarly, if I'm looking for information of the sites of multilateral organizations and organizations working with the population of the base of the pyramid and considered by authors such as CK Prahalad as examples of positive impacts to the population.

\section{b) Selection of publications in database}

The publications were extracted from database using the terms "base of the pyramid", "bottom of the pyramid", "design management", "process design" "poverty", "design", "innovation", "strategic", "Ashoka", "Social alliances", "Grameen", and "Prahalad" the combinations used for the search were "bottom of pyramid" and "design management", "bottom of pyramid" and "design process", "innovation" and "bottom of pyramid", and "design" and "bottom of pyramid".

\section{c) Filters}

These references were filters and then analyzed; the articles were filters by area of expertise: engineering, Business, management, and accounting, social sciences and economics, econometrics and finance, and temporal filters have applied since the year 2002. Because these are indications of scientific advancement and because they are, peer reviewed by the scientific community obeying the formal evaluation criteria.

\section{d) Content Analysis}

These articles were categorized and analyzed from a systemic perspective, identifying who is the population of the bottom of the pyramid, and how this market represents an opportunity for organizations and entrepreneurs. Know the success of some cases of organizations and entrepreneurs who worked there in these markets and which were the studies in design management, in terms of products, services and operations.

\section{Steps}

The research was carried out from March to May of 2014. It was divided into four stages. The first step was the identification of the problem. The second was the presentation of the concepts relating to the population of $\mathrm{BoP}$ and the design management. The third one present a discussion of cases and market opportunities of some organizations and entrepreneurs, through research into articles; and step 4 are the final considerations, as presented in figure 2 .

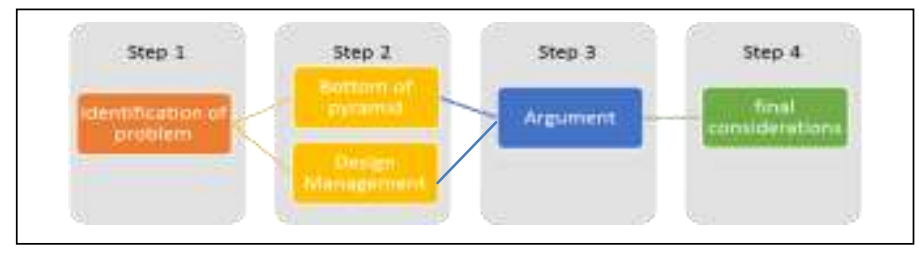

Figure 2. Steps (Prepared by the author)

\section{Theory}

\section{A. Bottom of the pyramid}

According to Prahalad, Di Benedetto, Nakata (2011), it is important to begin with a brief description of the features of the BoP market is more than four billion people who live on less than \$ 2 a day, even Prahalad, Di Benedetto, Nakata (2011), says, however, these four billion people that make up the BoP are not a monolith. They represent multiple cultures, ethnic backgrounds, levels of education, skills and needs. They can be segmented in various forms. This opportunity enabled segmentation, since the publication of the book the Fortune at the bottom of the pyramid (Prahalad, 2004), a proliferation of books and articles, as the next billion (Bhan and Tait, 2008) and The Bottom Billion (spoon, 2007). The World Resources Institute and International Finance Corporation (IFC) made a detailed study of BoP in all over the world, and it is estimated that the $\mathrm{BoP}$ is about 5 trillion (World Resources Institute, 2007).

According to the World Bank (2014), the population of the bottom of the pyramid collectively spends more than $\$ 5$ trillion per year. In fact, the lowest consumption segments spend more than the average consumption and higher segments combined. They spend \$2.3 trillion a year on food and drinks. As exemplified in the figure 3 .

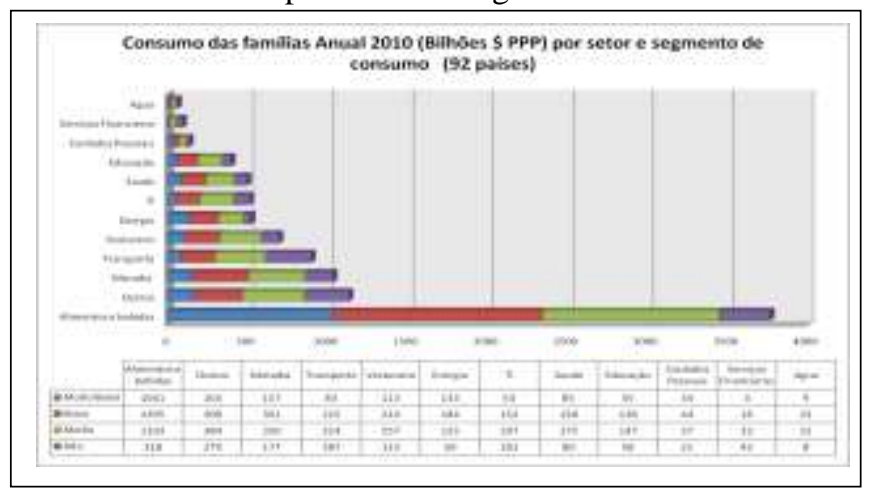

Figure 3. Annual Consumption of families 2010 (Billion \$PPP) by segment and consumption. (Adapted World Bank; 2014) 
The food and beverage market in lower consumption is significantly higher than the market in the medium and high segments combined, the same happens in energy expenses and personal care. In most other industries, clothing and footwear, housing, education, health and water consumption lowest segments collectively spend about as much as those in the higher segments do.

According to Prahalad and Hart (2002) explained, the world's economic pyramid is built on four levels, with the bottom layer represents four billion people with purchasing power parity of less than $\$ 1,500$ a year. This last group survives on less than $\$ 2$ a day; three-quarters of them live in Brazil, China, India, Indonesia, Mexico, Russia, South Africa, Thailand and Turkey. Knowing the buying power and behavior of these consumers, appear significant opportunities to meet your needs, through marketing strategies and design of products and services, increase your productivity, income and facilitate their entry into the economy (HAMMOND; KRAMER; KATZ, 2007).

Second Hammond; Kramer; Katz (2007), the starting point of this argument is not the poverty of the BoP, however, is the fact that a large part of the population of the BoP is not integrated into the global market economy and does not have a benefit of it. In addition, other elements are important to consider this whole segment of the population as the basic needs Unsatisfied, where most people of the BoP have no access to modern financial services. Dependence of informal means of subsistence, the majority of the population of the BoP does not have adequate access to markets to sell their work, and have no choice but to sell to the local employers or intermediaries that oppress. Are also affected by "sanctions the BoP", where many people pay higher prices for basic goods and services that consumers richer, and generally receive lower quality.

According to Prahalad (2004), suggests that the poor also have buying power and that it is possible for companies to sell their products for them, obtaining profit and recommends consider the world's poor as a large latent market. If we stop thinking of the poor as victims or as a burden and start to recognize them as resilient entrepreneurs, creatives and value-conscious consumers, a new world of opportunities will be presented.

Multinational corporations have mobilized resources quickly to take advantage of new developments to establish operations in poorer nations, and small and medium-sized enterprises (SMEs) are following the example. These corporations need to invest heavily in research and development (R\&D), understanding the complex local contexts, applying appropriate technologies, and build confidence. None of these tasks is trivial, but they are all critical to establish a foothold in these Nations. (BORADKAR, P; KULKARNI, U, 2010). An entrepreneur must reach beyond to create an organization, must be open to making mistakes, innovate, take risks, launch an unknown market, and do things differently. To undertake in the BoP, commences with a decision to improve the quality of life of this population, transforming your vision to generate incomes and have a strategy. A social entrepreneur creates a new radical solution to a social problem with the potential to revolutionize an entire industry. Social entrepreneurs have powerful new ideas that change globally and systems show vision compromised and inexhaustible determination, seeking to change an entire system. (SEM, P, 2007).
Second Boradkar, Kulkarni, (2010) the new business model predicated on three assumptions: the population of BoP that currently represents a latent market can be transformed into consumers, thus eradicating poverty through an appropriate business development. It presents, therefore, new opportunities for growth and innovation, making it a key market for companies, rather than a single recipient of charity or funds of corporate social responsibility (CSR) and show on the figure 4.

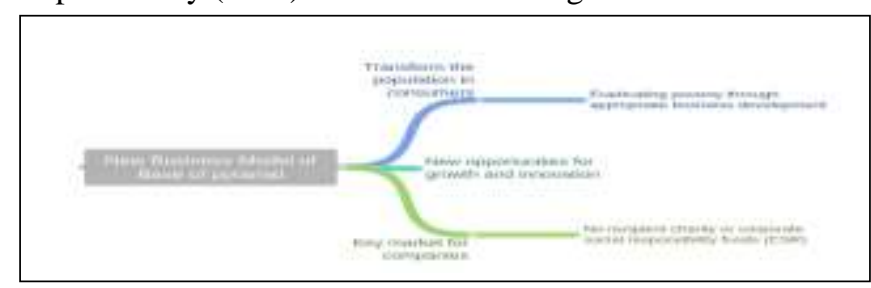

Figure 4. BoP Business model. (Adapted BORADKAR, P; KULKARNI, $\mathrm{U} ; 2010$.)

\section{B. Design management}

The management of the design is design activities that involve creative visualization of concepts, plans and ideas, which represented on sketches, and provides instructions on how to create something that does not yet exist, or at least not in the form provided (Walsh, 1996 and Bruce; Cooper, 1997). The Act of design requires a combination of logical and intuitive thinking. The Design is crucial to innovate and represents your creative aspect in which ideas put into material form. It is based the union, the combination of technical capabilities and demands of consumers (WALSH .1996).

Design management in markets of $\mathrm{BoP}$ is a continuous process of learning, improvement and understanding the market, companies and entrepreneurs need to identify simple, functional solutions, in order to transform the quality of life of this population. To this end, it is imperative for a design team has a deep understanding of the context and needs of potential users of low income for the purpose of producing and developing products and services with creative approaches. (CASTILLO; DIEHL; BREZET, 2012).

According to Fernandez-Mesa (2013), design management is an enabler of innovation. It allows you to generate innovation and transform more quickly and efficiently. However, is also the process of design which allows you to define how you can innovate. Innovation requires two conditions to develop novelty and utility. In General, the requirement of novelty is checked when the innovation process puts into practice an invention, a scientific discovery or a new production or technical management and utility requirement is through its use or commercial success. If innovation involves new, or significantly improved, the service offered to clients is a product innovation.

Prahalad (2010) lists 12 specific principles of innovation that have to be considered for $\mathrm{BoP}$ markets and offer suggestions those corporations can adopt to be successful. Products and services in this market must demonstrate superior performance to price; incorporate emerging technologies; rethinking the notion of scale; minimization of waste; functionality and the way closely considered in product design; innovative products have to be accompanied by innovative services; the workforce and not qualified 
factor be taken into account; the client education; environment; the interface design must take into account the specific needs of populations with different levels of literacy; urban and rural markets may not be easy to reach; due to the challenges of geography and density and the quick changes of design may be necessary. (BORADKAR, P; KULKARNI, U; 2010) like a present to figure 5.

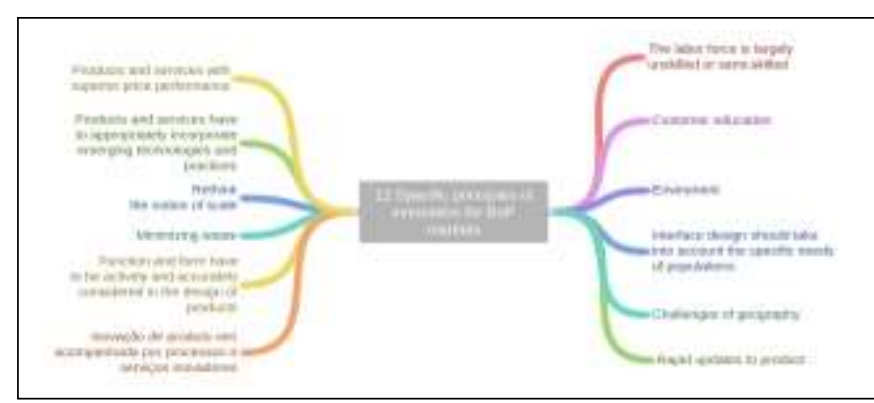

Figure 5. 12 Specific principles of innovation for BoP markets. (Adapted BORADKAR, P; KULKARNI, U; 2010.)

Contrary to popular assumptions, the poor can be a very lucrative market-especially if the multinationals adapt their business models. Specifically, the level four is not a market that allows traditional search high profit margins; instead, profits drive by volume and capital efficiency. The banks are likely to be low (to current standards), but the unit sales can be extremely high. (PRAHALAD, C.K.; HART, s., 2002). The success and some organizations and entrepreneurs in the market of the BoP, commences with create opportunities and design for creative solutions, breaking paradigms on the market of this population, in order to align economic and social interests, generating higher income and a better quality of life for the people.

The design process is described metaphorically as a system of spaces instead of a predefined series of steps ordered, these spaces distinguish between different types of related activities which together form an innovation (Brown, $\mathrm{T} ;$ 2008). The design approach has responsibility for the implementation of new ideas and strategies for these markets being an opportunity to apply innovations in products, services and operations, establishing and identifying new solutions to the consumer of the BoP.

The design allows you to use methods that can be useful for making quick decisions, an example may be the approach of thinking of design or design thinking, where you have a view of the problem. The mapping to assess the experience through the eyes of the customer, the analysis of the value chain that supports the customer experience, generation of ideas, brainstorming to generate new possibilities, innovative elements and tests are conducted with the main assumptions that will drive the success or failure of a concept. As a result, there is a prototyping where new concepts expressed tangibly, in this way; customers are involved in creating the solution that best meets your needs, in order to obtain an apprenticeship you can experiment to create a new experience and an affordable solution over an extended of time. (LIEDTKA, KING, BENNETT, 2013)

\section{Results and Discussion}

An example that involves this creative visualization of concepts and ideas by applying the strategies used to design management impact on the bottom of the pyramid is inclusive alliances. According To ISHIKAWA, A; MOREL,
R (2008), the private sector works with civil society organizations to create jobs, promote entrepreneurship, thus contributing to economic growth, integrating the lowincome population in its value chain and providing appropriate and affordable goods and services. The organization participates in this Alliance, without losing sight of our core business and its aim to generate profits and thus contributes to overcoming poverty and social exclusion.

A type of partnership is the relation between the Grameen Bank and Danone. These two organizations are the protagonists of a joint venture in 2006 (Grameen Danone Foods) and established a new model that considers the social causes and sustainability as core business factors.

Grameen Danone Foods purchase the poorest farmers milk in Bangladesh, which in turn acquire one or two cows through a microloan, and selling the product through a network of tents and kiosks operated by microentrepreneurs. For these communities, the project involves the improvement of the health and nutrition; while at the same time have an increase in rents. However, this would not happen if two completely different industries, such as micro financial and dairy products, there were no make a partnership to the lower classes.

Grameen Danone Foods produces and sells yogurt designed to provide the nutrients that often children are not, in rural areas of Bangladesh, where child malnutrition reaches very high levels. Through this initiative, the Danone extends their product to a new market, introduces nutritional products at reasonable prices and gets a new niche market that once was out of the reach of your business. In addition, be involved in a joint venture of this kind reinforces the good image, mainly because of being linked to a wellrecognized institution as the Grameen Bank, and work closely with a celebrity committed to the poor as Dr. Yunus, thus creating a positive effect on your reputation.

Based on the World Bank approach where the food and beverage market in lower consumer segments is significantly larger than other segments. Grameen Danone Foods, understood the problem, generating a concept, being this activity the beginning of the design process, which is linked to that was defined within the framework of the activities of management of the design and creation of a network of information, ideas and identification of user's needs. Once lifted the concept, devised the strategy of design and created a new operation rethinking the notion of scale, introduced in the population of the BoP in the center of the innovation process and the business strategy of Grameen Danone Foods and set resources, created and implemented a product with superior performance and successfully to the population.

Another example, using the design process that allows organizations and entrepreneurs across the barriers imposed on the bottom of the pyramid markets is the hybrid Value Chain, is a model that seeks to approach the companies and NGOs to co-create systemic solutions to achieve social change. (Budinich, 2005)

For Ashoka meet adequately the poor must move decisively to congruence between the business and social sectors. This means a commercial partnership, long-term focused and strategic in the use of the core competencies of the sectors, and designed to transform the economies and living conditions of low-income communities. This new 
type of social business model knows it as Hybrid Value Chain. (Budinich, V. 2005)

Through this model, companies can enter new markets and expand its customer's base, while social entrepreneurs expand their reach of social impact, expanding its services and accessing new sources of income. In addition, lowincome populations improve their quality of life through the satisfaction of their basic needs, emerging increasingly and new economic opportunities for them.

Retailers and financial companies like Casas Bahia of Brazil and Grupo Elektra from Mexico, are becoming leaders in their industry to expand aggressively its range of consumer goods and electronics to low-income families. Some are concerned that this trend of combining retail mix and financing of consumer goods, in many cases, the poor more. Others argue that it should be left to the choice of each of the consumers, and as such, offers are combined with significant opportunities to generate income, benefit the poor. However, what no one can argue is that profitable operations like Casas Bahia and Electra Group will keep growing and are proof of business opportunity in lowincome markets.

When it comes to satisfy basic needs such as electricity, housing and health, it is essential that those who are committed to the design of new offers identify ways to take advantage of the human and social capital of communities is intend to serve. Natura and Avon, both innovative companies in the cosmetics industry, creatively deployed the concept of "beauty consultants" on an unprecedented scale. These organizations have each, more than 400 thousand promoters that sell only in Brazil.

CEMEX, world manufacturer of cement, sent a team to live in a poor neighborhood for several months, with the only mission, meet the typical decision-making processes of low-income families when they build or improve their homes. The response was a combination of perceptions that led CEMEX to create "Patrimonio Hoy" (www.cemex.com/cc/cc_cc.asp), private housing programs for the population of $\mathrm{BoP}$ with but accomplishments in the world. Originally inspired by the concept of Grammen Bank Loan, CEMEX "Patrimonio Hoy" design an offer that calls on customers, mostly women, save around $\$ 10$ a week for a period of 70 weeks to finance the construction materials needed to build a new roof or add a room.

The hybrid value chain of organizations depends on the stage of the design process, design innovative products and services of social impact through systemic solutions. Where retail companies put the population of the $\mathrm{BoP}$, in the center of their processes, they know the problem, which is access to your products. With this conceived, an idea of impact was the access of their products through credit, rethinking the notion of scale, using resources wisely and support by process and innovative services to the success of its strategy.

For the case of Avon and Natura to understand the problem, to sympathize with how the user of their products, devised a creative idea, where success was the education of the client, an interface design to your specific needs of BoP with varying levels of literacy and offering products with superior performance in price.

CEMEX with your project, knowing successful experiences of other organizations apply the entire design process, understanding the population, to plan and formulate a strategy where the women of the BoP are at the heart of the innovation process. Explored the particular needs of the population in order to generate creative ideas as was the program designed, as if he knew the success of other organizations these were part of the test of your project in order to implement and executed the operation of the program.

Consumers of BoP if they differ significantly from the upper classes in their needs and how they are attracted by products and are highly sensitive to price, and value the functional use made in many commodities. The way they live and their daily needs require products with different features. Brand awareness is even greater, since it has an aspiration to a better quality of life and desire for status. (LOPPACHER; LAKE; LOITEGUI, 2011)

This was understood by the Nestle (especially in Peru and Brazil) for betting on solutions where presentation of edible products in smaller formats, often for daily consumption or individual consumption. These formats have made possible that consumers of the BoP would proceeded the vacuum brand products that before could not buy. (LOPPACHER; LAKE; LOITEGUI, 2011)

In the case of Nestlé, the design process, understood and adapted the necessary changes to its products, in the design of their packaging for entering a new market, innovation in processes and innovative services to meet the specific needs of the BoP, recognizing a problem of population with an agile approach and customized.

Another case is women in India and their hair. In a country with many poor communities and many cultural taboos related to luxury, views on clean hair often only indulgence of women. They rarely leave home with a hair out of place, and they are willing to explore opportunities for taking care of their wigs. However, there is a widespread belief that the cheaper shampoos are very detrimental to their wigs, and many low-income women preferring to use a single soap for hair and body. Instead of trying to combat this perception through marketing efforts widely held to increase the acceptability of inexpensive shampoo, Hindustan Lever decided to create a book for general purpose SOAP with special ingredients for a healthy hair. The great success of the new soap called "Brezee 2 in 1" and the distribution directed only to small towns and rural areas. (ANDERSON, J; MARKIDES, c. 2006)

The most successful innovators in BoP markets are often those that offer products or services that are adapted to the specific needs of the customers, making products with better performance and rethinking the function and shape of the products.

Among the basic functions of packaging is the protection/backup product, ergonomics and design of packaging, which facilitate the consumption or use of the product. As such, the package must protect and preserve their products in very good conditions and at all stages of logistics. For the population of BoP plays an important role, because if you have a dual functionality, has an advantage over competing products purchase.

From the point of view of dual functionality, you should consider other variables such as the conservation of the product, ease-of-use/consumption and recursion that the 
Proc. of The Third Intl. Conf. on Advances in Social Science, Management and Human Behaviour - SMHB 2015 Copyright ( ) Institute of Research Engineers and Doctors, USA .All rights reserved.

ISBN: 978-1-63248-067-5 doi: 10.15224/ 978-1-63248-067-5-65

population can give. Without doubt, the packages that are reuse in the world are the more plastic bag. It's converted into garbage bags or bags for transport of all kinds of things. Another package that has many features is the PET bottles, which may become a lamp, brick or a single pot to garden.

I agree that one of the strategies identified focuses on a specific topic as inclusive alliances of Grameen Danone Foods, generated a new operation, but leave behind the product and services. The strategy of hybrid value chains specialized in services in the case of CEMEX, which involving the design process for generate a new service for the population of BoP. Similarly, the adaptability and functionality this strategy more focused to the product, as in the case of Nestlé, which offers its products to the population of the $\mathrm{BoP}$, applying the design process in its packaging and presentation of the product, in synthesis presents a picture of each focused strategy depends on table 1.

TABLE I. Strategy Vs Process - Services - Product

\begin{tabular}{|c|c|c|c|}
\hline Strategies & Product & Services & Operation \\
\hline $\begin{array}{c}\text { inclusive } \\
\text { partnerships }\end{array}$ & & & Grameen Danone Foods \\
\hline hybrid value chain & & $\begin{array}{c}\text { Ashoka } \\
\text { Casas Bahia - Grupo Elektra } \\
\text { Natura - Avon } \\
\text { Cemex } \\
\end{array}$ & \\
\hline $\begin{array}{l}\text { adaptability and } \\
\text { functionality }\end{array}$ & $\begin{array}{c}\text { Nest le } \\
\text { Hindustan Lever }\end{array}$ & & \\
\hline
\end{tabular}

Design management can be the basis of the strategy of many organizations and entrepreneurs, generating value to them, brand differentiation in products, services and operations, generating positive impacts to their customers, in this case the BoP.

Based on the ten principles of Prahalad, if they can identify the strategies in the topics of innovative products, services and operations, enabling organizations and entrepreneurs across the barriers imposed on Bop markets, according to the following table 2 .

TABLE II. PRAHALAT PRINCIPLES

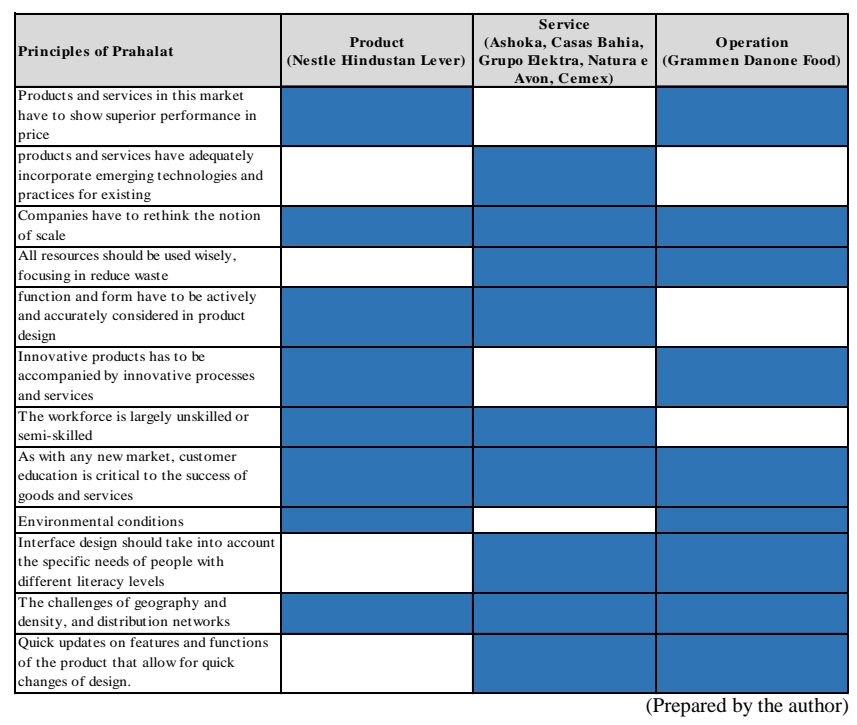

\section{v. FINAL CONSIDERATIONS}

According to IFC the four billion people representing the BoP spending collectively $\$ 5$ billion a year and spend half of their income on food. This is because the population of BoP is affected by these sanctions "that Hammond: Kramer: Katz (2007) present in his article, where they have to pay higher prices for basic consumer goods and services in this case food and drinks, being generally of inferior quality. The IFC Study makes it clear opportunity for companies in these markets; first, it is a market that generates more income than the markets higher levels of the pyramid. Second, identifies that the food and beverage sector, has a potential for development, with a focus on food companies, in a stage where they can research and create ideas of products, services and operations.

In the case of this article where GRAMEEN and DANONE FOODS, two organizations with no relationship, spawned a concept for the population, where for an approach for managing the design improve the food and also the generation of incomes for the people involved, made the identification of resources involved to develop this strategy.

- Understand the problem that happens;

- To perform this activity, to work with the people to understand the problem, in this case the poor nutrition and disability funds. ;

- Define and generate a comprehensive alliance to solve the problem identified;

In addition, they in their new operation decide to implement and as a result created an organization like GRAMEEN DANONE FOODS, as presented in figure 6.

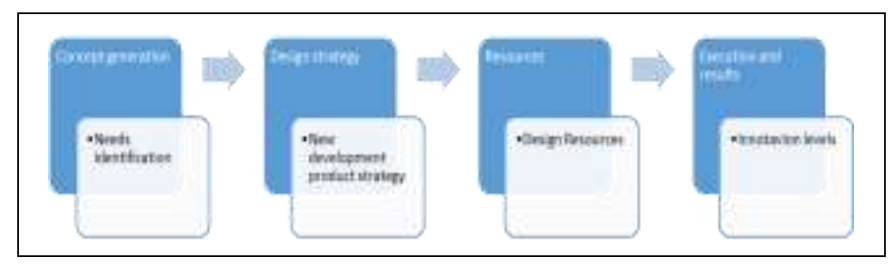

Figure 6. Design Process Management.

The population of BoP spends more money on food, and looking for alternatives to be able to spend in other areas, giving priority in housing and in the second option, health, education and personal care. The companies that work in these sectors have identified that financial services are the cornerstone to enter this market and generate a series of products and services, having the opportunity to turn the population into consumers.

Knowing the priority of the population, which is to acquire and improve their houses, CEMEX, understood that the BoP needs opportunities to develop and thus generate incomes. This is why generate a new product or service, creates a strategy, explores a market identified with a series of key needs, then held a series of feedback its strategy, and present a project that offers integrated solutions, accessible and adapted to the BoP.

Organizations with successful cases identified have developed models; strategies and methods for improved the quality of life of people, turning them into a population capable of generating value in the short, medium and long term.

As impact and key tool is the holistic view that some organizations working in support of the population of the BoP, determined that a linear vision focused on a single 
Proc. of The Third Intl. Conf. on Advances in Social Science, Management and Human Behaviour - SMHB 2015

Copyright (C) Institute of Research Engineers and Doctors, USA .All rights reserved.

ISBN: 978-1-63248-067-5 doi: 10.15224/ 978-1-63248-067-5-65

factor, like sales, is not the right way to enter these markets. To identify the design process as approach to engage this population throughout its value chain as suppliers, employees and customers.

Under a series of cases the design process allows you to identify strategies, changing the way of doing things. Besides, the systemic and holistic view helps to solve the problems depending on the approach to where you can see a series of elements that help to solve a problem in products, services and operations.

\section{References}

[1] PRAHALAD, D. Design Lessons from the Consumer at the Bottom of the Pyramid. 2011. Available at: <http://blogs.hbr.org/2011/05/design-lessons-from-the-consum/>. Access in: May 17, 2011.

[2] PRAHALAD, C.K.; HART, s. The fortune at the bottom of the pyramid: Low-income markets present the prodigious opportunity for the world's of the wealthiest companies - to seek their fortunes and bring prosperity to the aspiring poor. Strategy And Business Magazine, Boston, v. 26, p. 1-14, 2002.

[3] PRAHALAD, C.K. The Fortune At The Bottom Of The Pyramid: Eradicating Poverty Through Profits. New Jersey: Wharton School Publishing, 2010

[4] PRAHALAD, C.K.; Di BENEDETTO, A; NAKATA, c. Bottom of the Pyramid as a Source of Breakthrough Innovations. Journal of Product Innovation Management, Volume 29, Issue 1, January 2012, Pages 6-12.

[5] SCHUSTER, T; HOLTBRUGGE, d. Market entry of multinational companies in markets at the bottom of the pyramid: the learning perspective. International Business Review, Nurnberg, p. 819-830, 2012

[6] HAMMOND, L.; KRAMER, J.; KATZ, n. Los 4 Thousand Stations Millones: Tamaño Del Mercado Y Estrategia De Negocios En La Base De La Pirámide. Washington: World Resources Institute, 2007.

[7] NO, P; Ashoka's big idea: Transforming the world through social entrepreneurship. Futures. Gurgaon, p 534-553. 2007

[8] BORADKAR, P; KULKARNI, u. Design Tools for the Base of the Pyramid Strategies. Interactions. New York, p. 41-46. out. 2010.

[9] JAGTAP, S; How design process is the Base of the Pyramid differs from that for the Top of the Pyramid, Design Studies (2014), http://dx.doi.org/10.1016/j.destud.2014.02.007

[10] ISHIKAWA, A; MOREL, r. Cuadernos de la Cátedra la Caixa de la Empresa Social Responsability y Gobierno Corporativo y Partnerships between enterprises, organizations of civil society, In 2, IESE Business School Universidad de Navarra, 2008.

[11] BUDINICH, V; Market Strategies benefician the Poblaciones de Bajos Income. Mexico D.f: Ashoka. 2005.

[12] LOPPACHER, J.; LAKE, A.; LOITEGUI, J.. El Model de las 4: how to meet the base of pyramid en Latin America through it operational excellence. Harvard Business Review Latin America, p. 58-68, 01 Aug. 2011 Monthly.

[13] ANDERSON, J.; MARKIDES, c. Strategic Innovation at the Base of the Economic Pyramid. 2006. Available at: <http://www.researchgate.net/profile/Jamie_Anderson6/publication/2 28351536_Strategic_innovation_at_the_Base_of_the_Economic_Pyra mid/file/5046352945f51aa64f.pdf >. Access in: 01 Aug. 2006.

[14] LIEDTKA, J.; KING, A; BENNETT, k. Solving Problems with Design Thinking: Ten Stories of What Works. Columbia University Press, 2013.

[15] BROWN, t. Design thinking. Harvard Business Review, v. 86, no. 6, p. $84,2008$.

[16] MINAYO, Maria Cecília de s. (org.). Social research: theory, method and creativity. 9. ed. Petrópolis: Voices, 1998.

[17] GIL, Antonio Carlos. Methods and techniques of social research. 4. ed. São Paulo: Atlas, 1995.

[18] CASTILLO, L; DIEHL, I; BREZET, J.C. Design Considerations for the Base of the Pyramid (BoP) Projects. In: Proceedings of the Cumulus Helsinki 2012 Conference. 2012. p. 1-15.
[19] FERNÁNDEZ-MESA, Anabel et al. Design management capability and product innovation in SMEs. Management Decision, v. 51, n. 3, p. 547-565, 2013.

[20] Marketing News. La apuesta por la base de la pirámide. 2014. Available at: <http://www.marketingnews.com.co/la-apuesta-por-labase-de-la-piramide/>. Access in: May 19, 2014.

[21] PRAHALAD, c. k. the Fortune at the bottom of the pyramid: eradicating poverty through profits. 2004.

[22] WALSH, Vivien. Design, innovation and the boundaries of the firm. Research Policy, v. 25, no. 4, p. 509-529, 1996.

About Author (s):

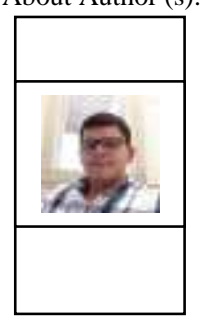

[For make business with four billion poorest people in the world, two-thirds of the global population, are required radical innovations in technology and business models (PRAHALAD, C.K.; HART, s., 2002). To work with this market, entrepreneurs and organizations have to meet the challenges affecting this population, in order to improve people's quality of life and reduce the inequality indices, being necessary for this, design appropriate products and services for this population.] 